\title{
DEVELOPMENT OF SOCIAL AND ENTREPRENEURIAL SKILLS OF STUDENTS OF ENGINEERING AND TECHNICAL SPECIALTIES IN THE MODERN UNIVERSITY
}

\author{
Evgeniya Liventsova, Tat'yana Rumyantseva ${ }^{\mathrm{a}}$, Ekaterina Syriamkina \\ National Research Tomsk State University, 634050, Tomsk, Russia
}

\begin{abstract}
The article analyses experience of the National Research Tomsk State University on development of social and entrepreneurial skills of students of engineering and technical specialties. The experience includes description of activity of the Park of social and humanitarian technologies, which is a TSU's structural unit. The article is based on analysis of global trends of university development, analysis of documents and practical experience in developing students' social and entrepreneurial skills and includes project- research experiment. The authors conclude that in current conditions training of students of engineering and technical specialties requires modern dealing with knowledge, focus on the synergetic development of the personality, integration of information with innovative methods of education and various forms of social and cultural activities.
\end{abstract}

\section{Importance of students' social and entrepreneurial competencies for innovative sphere}

Decree of the Government of the Russian Federation of March 16, 2013 № 211 «On measures of state support of the leading Russian universities in order to enhance their competitiveness among the world's leading research and education centers» and other strategic documents of the Russian Federation in the sphere of education and science, as well as competitiveness enhancement programs of the leading Russian universities provide for creation of favorable environment and conditions for the development of priority international areas of basic and applied research. The Strategy of development of information technology industry in the Russian Federation for 2014 - 2020 years and up to 2025 (the order of the Government of the Russian Federation of November 1, 2013 № 2036-r) emphasizes that institutions of professional and higher education should focus on development of business and entrepreneurial skills among students of engineering specialties. The Atlas of new professions - 2020 (the project, issued by Moscow School of Management «Skolkovo» and the Agency for Strategic Initiatives) stresses that «the modern world is changing so quickly that we can no longer afford to study theoretical disciplines for five years, and then take some time to master the profession for account of

${ }^{\text {a }}$ Corresponding author: rtb98@mail.ru 
an employer. Therefore, education, especially for university students, becomes more practical-oriented. This means that the emphasis is shifting from the theory to real students' projects, including their start-ups».

National Research Tomsk State University (TSU) is among the leading universities of Russia, whose competitiveness enhancement program received the highest assessment of the Council on improving the competitiveness of the leading universities of the Russian Federation. According to the plan of measures on realization of competitiveness enhancement program for 2013-2020, TSU has identified six key strategic areas of development. One of them is strategic direction for implementation of models and practices of successful international research universities.

The main activities under this direction include the following:

- creation and development of TSU centers of excellence on the basis of networking and interdisciplinary studies to provide international leadership in the field of research of quality of human life and society;

- development of network of engineering centers and collective use centers;

- organization of events on the federal and regional levels in the field of innovation, technology and social entrepreneurship;

- formation of entrepreneurial spirit and intensification of innovative activity among young people.

Development of youth entrepreneurship is also one of the priorities of the state program «Development of Entrepreneurship in Tomsk region». The program provides for allocation of significant budget funds to support and develop youth entrepreneurship and includes 14 measures aimed at involving young people in business. Activities include development of skills and knowledge in the field of entrepreneurship, enhancing of entrepreneurial competences, formation of a positive image of entrepreneurship among young people, testing and motivation to start entrepreneurial activity, creation of new business entities, access to finance, information and consulting support, development and support of youth entrepreneurship associations, and other activities.

Serious attention of public authorities to the development of youth entrepreneurship also reflects the results of studies of recent years, which indicate emerging difficulties in attracting staff for the small business sector. According to Tomsk oblast Administration Decree "On Approval of the State Program "Development of Entrepreneurship in Tomsk Oblast" of December 12, 2014 № 492a, these difficulties are associated with changes in the preferences of the most part of young people. Not only in Tomsk region, but also in Russia as a whole, young people tend to build future career with a view to employment in the public service or public corporation. This is because of apparent stability of this sector of the Russian economy, and, at the same time because of the nature of business risks.

A similar trend is also confirmed by the results obtained during the study «Investment Activity of University Students of Tomsk», conducted by specialists of the departments of sociology and social work of the Faculty of Philosophy of Tomsk State University in 2013 (Figures 1 and 2).

According to the study, the proportion of students who already had their own business was low $(2 \%)$; only one of ten students $(12 \%)$ were going to start their own business in the near future. Less than a tenth part of students pointed their unwillingness to develop own business $(9 \%)$. The vast majority did not plan to develop own business, but considered this opportunity in the future $(68 \%)$. Other students realized that they would be employees in the public or private institutions. Among those who were planning their own business, the majority $(60 \%)$ focused on traditional sectors of economy - the sphere of trade, services, etc. The rest were ready to consider business opportunities in innovative sphere (40\%) [1]. 


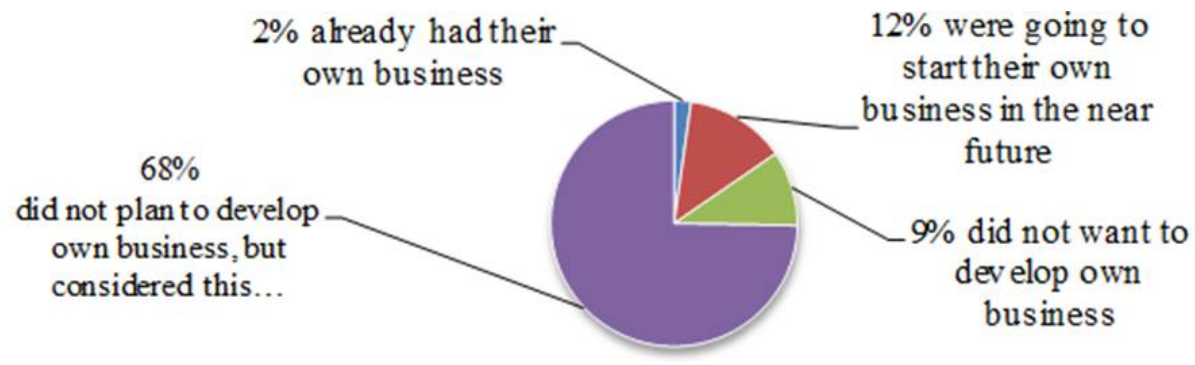

Figure 1. Attitude to own business of students of Tomsk universities.

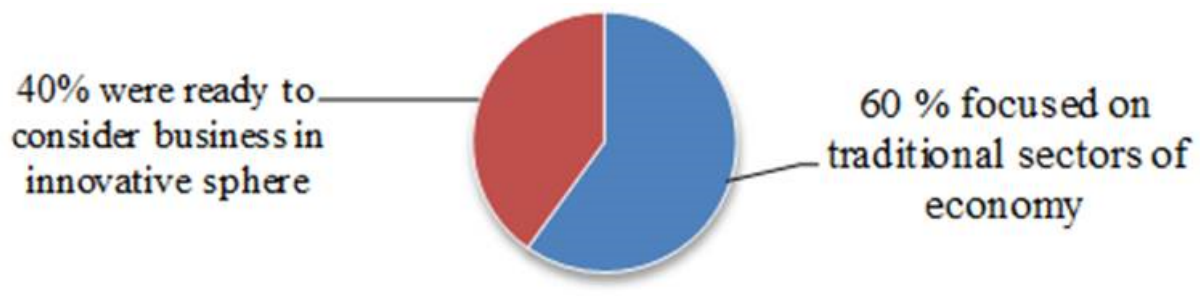

Figure 2. Preference to own business direction of students of Tomsk universities.

Thus, the local community, and especially the universities, face the problem of propaganda of self-employment and a positive image of entrepreneurship among the youth, as well as formation of social, professional skills of students of engineering and technical specialties and provision of information and consulting support.

A system of business support infrastructure is formed in the Russian Federation in order to prepare young people for entrepreneurship. Under the RF Federal Law «On Development of Small and Medium-Size Business in the Russian Federation» of July 24, 2007, hundreds of business incubators, dozens of venture funds, special programs for small and medium-sized enterprises operate all over the country at the federal, regional and municipal levels. The characteristic feature of the Russian infrastructure of support of small and medium-sized enterprises is focus on support of enterprises in scientific, technical and investment spheres, «a shift towards innovative small businesses». Analysis of the structure of the organizations forming the infrastructure of business support in the regions also confirms this fact. For example, in Tomsk region there are more than fifty infrastructure elements, including special economic zone, engineering center, cluster development center, nanotechnology center, center for stimulating demand for innovative products, student and technological business incubators, offices for commercialization development at universities and academic institutions, youth innovative creativity centers, technology transfer centers, Tomsk venture fund, consortium of Tomsk universities and research organizations, a network of venture financing, consulting companies and other organizations. This fact is proved by Tomsk oblast Administration Decree "On Approval of the State Program «Development of Innovative Activity and Science in Tomsk oblast» of October 30, 2014 № 414a.

Some experts believe that the current Russian system of business support does not correspond to sectorial structure of the national economy and social sphere of the country. Experience of some foreign countries on formation of business support policy, Great Britain, in particular, shows that policy aimed mainly at supporting specific industries that could positively affect the development of the region in the future, over time changes in the direction of creating favorable conditions for business development on the whole [2]. 
Report on the main results of the system of higher and professional education in Tomsk region in 2014 shows the tendency for orientation towards innovative small business in institutions of higher education, including universities. They create student and technological business incubators, commercialization offices, technology transfer centers, small companies form an innovative university belt. The total number of innovative companies of National Research Tomsk State University was 51 in 2014, including 14 companies created in 2014.

Preparing students to innovative and entrepreneurial activity in science and technology is also in the list of priorities of the Government of the Russian Federation. For nearly 10 years the Foundation for assistance to small innovative enterprises in scientific and technological sphere has implemented «UMNIK» program aimed at promoting mass participation of youth in science, technology and innovation. The program provides support to young scientists seeking to realize their potential through innovation, as well as stimulates young scientists to create small innovative enterprises for commercialization of research results.

However, in modern conditions, it becomes obvious that the higher education training system in addition to providing traditional knowledge in a particular field of science needs to prepare specialists with broad outlook, more advanced communication skills, willingness for cooperation and life-long training. Many world leading countries follow this approach to training in engineering. In particular, in the USA the number of basic principles of engineering education includes the need to provide strong foundations of knowledge in mathematics, physics and engineering sciences; the importance of experimental design and laboratory work; the need to develop social skills of engineers; the need to include social, economic and human sciences in the curriculum; the need to prepare students for lifelong education.

TSU professors V. Klochko and E. Galazhinskiy have studied various empirical indicators and personal criteria related to the processes of motivation to innovate activity by exploring persons who exhibited inclination to entrepreneurship and innovation or achieved significant results in this sphere. The researchers tried to determine personal qualities, potentials, resources necessary for a person to be capable to carry out innovative and entrepreneurial function. According to the results of the study, innovative potential includes the following:

1. Personal qualities such as tolerance to uncertainty, ability to take justified risk, responsibility, need for self-realization, motivation to achievements, reflexivity, creativity (the quality of intelligence, intellectual initiative).

2. Competence, including project-design, communicative and information competence.

3. Vitality (special features of value-semantic organization of the life-world, viability, sovereignty, ability to work, mobilization potential, level of self-control, human orientation towards a certain quality of life) [3].

\section{Role of the modern university in development of students' social and entrepreneurial competence}

Today, institutions of higher education should focus on the global and national trends in order to increase their competitiveness.

1. Modern society increasingly requires active participation of universities in economic and social development. The process of education system reforming must consider this trend. Member countries and partner countries of the organization for economic cooperation and Development (OECD) consider the third role of universities as one of the key indicators of higher education development. 
Program of TSU strategic development as a national research university for 2010 2019 highlights socio-humanitarian knowledge and technologies in modernization of economy and social sphere as one of the main direction. Moreover, among provincial universities with the status of national research university, only TSU has announced humanitarian studies as one of the priority research areas.

2. The document prepared based on results of the "University and Community» project conducted by «New Eurasia» Foundation, describes the conceptual model of socioentrepreneurial university and highlights its main characteristics. The idea is that an university earns not only on traditional educational programs for the traditional target group, but also initiates and implements innovative social and business projects together with representatives of the local community [4]. First, the university should be open to the community. Openness here means both involvement of representatives of non-academic environment in the educational process and inclusion of direct experience of work in community in the educational process. For example, during a training course a student gains practical experience in a business company under the supervision of a tutor. Such programs are common in the US and Europe and are highly popular among teachers and students. They enable to find and propose solutions to various problems of the local community during the educational process.

3. Influence of the university environment to innovative activity is reflected in the theory of the "Triple Helix», introduced in England and the Netherlands by Henry Etzkowitz, professor of Newcastle University, and Loyetom Leydesdorf, professor of Amsterdam University, at the beginning of the XXI century. The triple helix symbolizes alliance between the government, business and universities, which are key elements of the innovation system of any country. This theory shows their interaction at every stage of creation of an innovative product. Government and university interact on the initial stage of knowledge generation; university works with business during the process of technology transfer; government together with business bring the result to the market. The role of the university in the triple helix model is undeniable.

Based on the great experience of training specialists in social and humanitarian sphere and taking into account global trends, Tomsk State University started to pay more attention to development of social skills, including students of engineering and technical specialties. This means business activity in the social sphere, which leads to the development of interpersonal skills, system thinking, formation of an active lifestyle and professional positions, ability for effective team communication, learning of the basic principles of behavior on the labor market.

\section{Development of social and entrepreneurial competence of students of engineering and technical specialties}

Currently, the basic list of subjects in university curriculum does not include learning the basics of social, project activities, and entrepreneurial culture. Meanwhile, any person with appropriate inclinations can be an entrepreneur. Therefore, this activity is a subject to strong influence of accidents, a variety of different sources of replenishment, is joined with a number of other activities and involves intensive exchange of experience, skills, methods, knowledge and tools. All this contributes to the viability of businesses. In the business environment, there is a place for development of personal creativity, strong-willed, intelligent and energetic properties.

A system of education, especially professional, influence greatly the desire to become an entrepreneur (in any field). Results of a study conducted in Canada showed that people 
with low level of education tended to have a low income and did not seek to create their own businesses, while highly educated people tended to open their businesses, both for getting sufficient income, and for achievement of self-realization and independence. People with average level of education, by contrast, did not consider their own business as best option, and preferred to be hired employees. The study also found that university education increased people's desire for self-employment by $8.6 \%$ on the average, including men - by $12.9 \%$, women - by $6.1 \%$. In general, the results obtained by researchers established a clear relationship between self-employment and a person's level of education: lower education significantly reduced the likelihood of self-employment [5].

Higher education institutions face a number of problems in order to generate a new wave of entrepreneurs. First, it is recognition of persons capable of business activities in order to provide further assistance to them in improving the appropriate inclinations. Because talent or ability to entrepreneurship can be not found, and will just disappear. The solution to this problem requires for thoughtful individual work with students. Second, establishment of creative atmosphere in educational institutions, in order to provide conditions for realization of manufacturing independence, initiative, activity; striving for identification of problems that can be of great practical importance and a subject for students' serious inspiration. Third, a broad demonstration of various forms and types of businesses, lives and practices of successful entrepreneurs. It is important to acquaint students with work and experience of entrepreneurs in various spheres. Finally, fourth, development of education through various forms of students' universal social competences, which allow being competitive in any field.

Humanitarian sciences play a major role in formation of social competence of students of technical specialties. When acquiring knowledge in humanitarian sciences along with technical science, a student gets world outlook and values and becomes a subject of his own life. According to British psychologist J. Raven, involvement in a certain activity is critical for competence development; this means that it is important to have a purpose, for which a person will act, the intensity of individual motivation determines the level of competence manifestation [6]. Thus, the development of any activity must be based on strong ideas about its social and subjective significance, usefulness of the results. The entrepreneurial component becomes an integral part of any professional activity and provides prestige of any profession, as it allows people to adapt it to the conditions of today's market. The desire of young professionals, including engineers, to create and implement their own business projects, is an indicator of their social and economic competence, manifestation of an active life position, readiness to solve the urgent problems facing society, or simply to create a product necessary to the consumer.

Realizing that the concepts of «innovation potential» and «entrepreneurial resource» are largely connected with the individual's creativity, TSU has created a structural unit - Park of social and humanitarian technologies (hereinafter - the Park) aimed to implement the above-mentioned technologies of work with students both of social and humanitarian sciences and engineering and technical sciences. Another aim of the Park's activity is to involve students in social and entrepreneurial activity, as well as to attract professional experience of members of the local community (including business) to the university.

The Park's goal is to organize environment for innovative development of university students in order to enhance social and humanitarian technologies, social entrepreneurship. To achieve this goal, the Park tries to solve such problems as formation and development of conditions for commercialization of innovative projects based on the results of social and humanitarian research; involvement of students and employees of TSU to the process of creation, development and implementation of innovative humanitarian projects; involvement of TSU students and employees in entrepreneurial activities; coordination of interaction between society, government and business organizations in development and 
implementation of social and humanitarian technologies. During 2012-2015, the Park's staff has implemented the strategy of development of entrepreneurial competencies of students of various specialties. Now, the Park successfully implements technologies of generating innovations in the social sphere.

The Park builds its work with students in three structurally and substantively related areas:

1) «From an idea to a project» (identifying student's creative ideas and raising them to the project activities).

2) «From a project to a technology» (expert evaluation of student's projects and developing them in social technologies).

3) «From technology to commercialization» (launch of technologies to the local community market, development of social entrepreneurship among university students).

All three stages contribute to the development of students' social and entrepreneurial skills. In this logic, the first direction is very important, in which initiation and incubation of students' ideas occur.

Among examples of the Park's initiation of students' project ideas is an annual internet competition of creative ideas «Student's Tomsk», purpose of which is search for student's creative ideas (including technical and IT - oriented ideas) relevant to solution of social problems Tomsk.

A social tutor (usually, the term «social tutor» is used in connection with socialization of graduates of boarding schools. The Park uses this term in connection with tutoring of social initiatives, in the meaning of «socialization» and promotion of students' ideas and projects) starts to work with winners of the competition. The first thing is joint drafting of a road map for the development of the project idea with designation of educational, competence and resource deficiency in the idea promotion. This allows the idea to become a full and long-term project.

At the stage of «From design to technology», experts support sustainable projects and analyze the project in terms of its possible technologizing. Representatives of relevant agencies and local community work as experts and think over the possible scaling and replication of technologies, as well as over their launching in social or innovative business mode.

The Park's direction «From technology to commercialization» is a priority. The Park organizes annual social investment contest aimed at investors' selecting and funding of social innovative technologies and services of student organizations-winners. The contest organizers encourage any form of interaction suitable for entrepreneurs: tutoring of a student association by a business support teacher, individual investment in activities of socially oriented student associations. Thus, long-term mechanism for promotion of university youth's innovative social services on the regional market is working.

Competitive mechanisms contribute to the development of students' entrepreneurial competences and social investment, even in a non-traditional form, enables to hold the students' interest for the further development and implementation of their projects. There are several reasons for this. First, the project team receives professional evaluation from experts. Second, these competitions are rather directed on the developing students' business and communication skills (the ability to negotiate with a sponsor or an expert on joint activity) than involve financial rewards. Third, the success of competitions largely depends on the training component of the student teams. An obligatory condition for students' participation in competitions is taking additional educational programs aimed to develop social and entrepreneurial skills of students of different specialties.

During 2012-2015, in cooperation with experts from local community the Park has realized a new educational program «Social accelerator» aimed to get acquainted TSU 
students with the phenomenon of social entrepreneurship. Educational subjects presented in the program are unique to all university specialties. This program is created for youth teams who have elaborated the idea of social startup as well as for youth teams who are implementing a social startup. Representatives of social business and socially responsible companies, who are ready to share their successful experience, representatives of government and social-educational institutions work as experts and mentors within the educational program.

The Park's specialists and experts have developed entrepreneurial campus training course «Three Steps to Entrepreneurship» for students who do not yet participate in the Park's activities. The educational program of the course consists of three main steps: «immersion», «learning», «testing». This course is universal. It has been successfully adapted to different areas of students training in TSU.

Thus, today the Park successfully implements active educational technologies for development social and entrepreneurial competencies of students of different specialties. Table 1 shows the summary data.

Table 1. Formation of social and entrepreneurial skills of students of engineering and technical areas inside and outside the educational institution (university).

\begin{tabular}{|c|c|c|c|}
\hline $\begin{array}{l}\text { Educational forms } \\
\text { (workshops, } \\
\text { training courses, } \\
\text { accelerators) }\end{array}$ & $\begin{array}{l}\text { Competitive } \\
\text { mechanisms } \\
\text { (Social, business } \\
\text { and research } \\
\text { competitions in } \\
\text { the university and } \\
\text { outside) }\end{array}$ & $\begin{array}{l}\text { Project technologies } \\
\text { (Initiation and } \\
\text { implementation of own } \\
\text { social and business } \\
\text { projects in volunteer } \\
\text { centers, youth public and } \\
\text { scientific associations, in } \\
\text { the local community) }\end{array}$ & $\begin{array}{l}\text { Forms of } \\
\text { support } \\
\text { (tutoring, } \\
\text { expert } \\
\text { evaluation, } \\
\text { mentoring) }\end{array}$ \\
\hline $\begin{array}{l}\text { Contribute to } \\
\text { successful } \\
\text { development of } \\
\text { social competence } \\
\text { of future engineers, } \\
\text { as the nature and } \\
\text { structure of } \\
\text { students' cognitive } \\
\text { activity } \\
\text { fundamentally } \\
\text { changes during the } \\
\text { learning process; it } \\
\text { leads to } \\
\text { development of } \\
\text { personal creative } \\
\text { potential }\end{array}$ & $\begin{array}{l}\text { Stimulate the } \\
\text { emergence of } \\
\text { students } \\
\text { entrepreneurial } \\
\text { skills, develop } \\
\text { such qualities as } \\
\text { risk tolerance, } \\
\text { self-organization, } \\
\text { consistency, } \\
\text { communication } \\
\text { skills, and other; } \\
\text { enables to } \\
\text { undertake entrepreneurial } \\
\text { testing }\end{array}$ & $\begin{array}{l}\text { Enable to expand students' } \\
\text { skills for project } \\
\text { development, skills for } \\
\text { teamwork and other } \\
\text { important skills; } \\
\text { enable to support and } \\
\text { stimulate active students' } \\
\text { interest to generation of } \\
\text { new ideas and bringing } \\
\text { them to the project activity } \\
\text { stage }\end{array}$ & $\begin{array}{l}\text { Allow } \\
\text { students to } \\
\text { pass through } \\
\text { all stages of } \\
\text { social and } \\
\text { business } \\
\text { design more } \\
\text { successfully }\end{array}$ \\
\hline
\end{tabular}

\section{Conclusion}

Thus, along with development of students' professional competence in the specific field of activity we draw attention to importance of development of personal (initiative, achievement drive, etc.) and social competence (ability to work in a team, to communicate effectively with the target groups, etc.). Practice-oriented training contributes to development of social and entrepreneurial skills of students of engineering and technical areas of training in a modern university. In turn, currently developing mechanisms such as 
social investment and strategic partnership of business community with universities provide benefits to each participant. Students get the possibility to carry out professional tests during the basic education; the university get possibility to apply innovative approaches in education; business gets human resources and valuable information in the form of nonstandard student ideas and solutions.

In conditions of transition of the global economy to the sixth technological cycle, promotion and commercialization of technologies require technicians and managers «of a new breed»; therefore, there is need to redefine teaching methods. High education is becoming one of the leading areas of activity in the sixth technological cycle, in which the value of a complexly organized person increases significantly. Therefore, personnel training should pay special attention to «creative practice». Motivation and interests of students are the key and most expensive resources for education efficiency. Renewal of education requires modern dealing with knowledge, focus on the synergetic development of the personality, integration of information with innovative methods of education and various forms of social and cultural activities [7]. The totality of the abovementioned forms of educational technology allows motivating students to obtain entrepreneurial skills. In this case, it is important for a student to determine the result of his efforts as possible realization in practice of important to society social and entrepreneurial skills that he has obtained at the university. In addition, this approach (use of aggregate educational technology) can overcome the gap between the theoretical training of students within the framework of the basic educational programs of the university and the practical experience, since any activity loses sense if it does not meet the needs of a modern society.

\section{Acknowledgements}

The paper was written as part of the research project No. 8.2.31.2015, carried out with the support of the Program "Research Foundation of Tomsk State University named after D.I. Mendeleev" in 2015 - 2016, grant RFBR No. 16-29-12858.

\section{References}

[1] V. Mikhailov, Expert-online Journal (2013) URL: http://expert.ru/siberia/2013/33/investor-na-shest-let/ (Assessed 01.02.2016).

[2] N. Williamsand, T. Vorley, Entrepreneurship and Regional Development 26, 257 (2014) doi: 10.1080/08985626.2014.894129

[3] V.E. Klochko, E.V Galazhinsky, Bulletin of the Tomsk State University (325), 146 (2009)

[4] J. Boshee, Nonprofit World 19, 15 (2001)

[5] O. Masakure, Education Economics 23, $693 \quad$ (2015) doi: 10.1080/09645292.2014.891003

[6] Dzh. Raven, Competence in modern society (Kogito Center, Moscow, 2002)

[7] V.I. Syryamkin, E.G. Syryamkina, Proceedings of the International Conference on Research Paradigms Transformation in Social Sciences 2014 (RPTSS-2014) 166, 468 (2015) doi: 10.1016/j.sbspro.2014.12.556 